\title{
New Nile Blue Derivatives as NIR Fluorescent Probes and Antifungal Agents ${ }^{\dagger}$
}

\author{
Rui P. C. L. Sousa ${ }^{1,2}$, João C. C. Ferreira ${ }^{1,2}$, Maria João M. F. Sousa ${ }^{2}$ and M. Sameiro T. Gonçalves 1,* \\ 1 Centre of Chemistry, University of Minho, Campus of Gualtar, 4710-057 Braga, Portugal \\ 2 Centre of Molecular and Environmental Biology, University of Minho, Campus of Gualtar, 4710-057 Braga, \\ Portugal \\ * Correspondence: msameiro@quimica.uminho.pt \\ + Presented at the 22nd International Electronic Conference on Synthetic Organic Chemistry, 15 November- \\ 15 December 2018; Available Online: https://sciforum.net/conference/ecsoc-22.
}

Published: 14 November 2018

\begin{abstract}
The synthesis of four new Nile Blue derivatives with hydrogen, propyl and/or aminopropyl groups as substituents of the amines of 5- and 9-positions is described. Photophysical properties were evaluated in acidified ethanol and aqueous solution at physiological $\mathrm{pH}$. Antifungal activity is also studied through the obtention of MIC values.
\end{abstract}

Keywords: benzo[a]phenoxazines; Nile Blue derivatives; NIR fluorescent probes; antifungal agents

\section{Introduction}

The development of new near-Infrared (NIR) fluorescent probes is a very important issue due to the wide range of applications [1-4]. These probes are an excellent choice to label biological material since its emission will not interfere with the natural fluorescence of biological compounds. Benzo[a]phenoxazinium salts, with Nile Blue being the best known, display fluorescence at around $600 \mathrm{~nm}$ and have been used as covalent and non-covalent fluorescent probes for amino acids, proteins and DNA, among other biological material [5-10]. In addition, applications as sensors or agents for photodynamic therapy (PDT) have been described [11,12]. Furthermore, medical applications of these compounds have been found, showing antifungal and antimalaria capacities [13-15].

Considering all these facts, the synthesis of four new benzo[a]phenoxazinium chlorides possessing one or two propyl groups at the 9-amino position and the aminopropyl group or a single hydrogen atom at the 5-amino position was carried out. Photophysical properties in ethanol acidified with trifluoroacetic acid (TFA) and in aqueous solution at physiological $\mathrm{pH}$, as well as the antifungal activity of all these compounds were evaluated and are described.

\section{Results and Discussion}

Benzo[a]phenoxazinium chlorides $\mathbf{1} \mathbf{a}, \mathbf{b}$ and $\mathbf{2} \mathbf{a}, \mathbf{b}$ were synthesized by condensation of 5-(dipropylamino)-2-nitrosophenol hydrochloride or 5-(propylamino)-2-nitrosophenol hydrochloride with naphthalen-1-amine and $N^{1}$-(naphthalen-1-yl)propane-1,3-diamine hydrobromide. Nitrosophenol hydrochlorides were obtained by nitrosation of the 3-(dipropylamino)phenol or 3-(propylamino)phenol with sodium nitrite in the presence of hydrochloric acid.

The benzo[a]phenoxazinium chlorides $\mathbf{1} \mathbf{a}, \mathbf{b}$ and $\mathbf{2} \mathbf{a}, \mathbf{b}$ were obtained as blue solids in $18-49 \%$ yields (Figure 1). All compounds were fully characterized by the usual analytical techniques. 
The ${ }^{1} \mathrm{H}$ NMR spectra exhibited aromatic protons of the polycyclic system $(\mathrm{H}-1, \mathrm{H}-2, \mathrm{H}-3, \mathrm{H}-4$, $\mathrm{H}-6, \mathrm{H}-8, \mathrm{H}-10$ and $\mathrm{H}-12)$ at $\delta 6.86-8.96 \mathrm{ppm}$. The terminal methyl groups at the 9-amino position appeared as triplets or multiplets $(\delta 1.04-1.12 \mathrm{ppm})$, adjacent methylene protons as quintets or multiplets $(\delta 1.70-1.81 \mathrm{ppm})$ and methylene protons adjacent to the nitrogen atoms as triplets or multiplets $(\delta 3.45-3.62 \mathrm{ppm})$. Methylene protons of propylamino groups at the 5-amino position for compounds 1a and 2a appeared as triplets, multiplets or broad singlets at $\delta 2.20-2.32 \mathrm{ppm}$ $\left(\mathrm{NHCH}_{2} \mathrm{CH}_{2} \mathrm{CH}_{2} \mathrm{NH}_{2} \cdot \mathrm{HBr}\right), \delta$ 3.20-3.24 ppm $\left(\mathrm{NHCH}_{2} \mathrm{CH}_{2} \mathrm{CH}_{2} \mathrm{NH}_{2} \cdot \mathrm{HBr}\right)$ and $\delta$ 3.84-3.87 ppm $\left(\mathrm{NHCH}_{2} \mathrm{CH}_{2} \mathrm{CH}_{2} \mathrm{NH}_{2} \cdot \mathrm{HBr}\right)$.

The ${ }^{13} \mathrm{C}$ NMR spectra showed the aromatic carbons of benzo[ $\left.a\right]$ phenoxazinium core $(\delta 94.14-$ $164.62 \mathrm{ppm})$. Methyl and methylene carbons of the propyl groups at the 9-amino position of di-alkylated compounds 1a,b appeared at $\delta 11.41-11.54 \mathrm{ppm}\left(\mathrm{N}_{(}\left(\mathrm{CH}_{2} \mathrm{CH}_{2} \mathrm{CH}_{3}\right)_{2}\right), \delta 21.76-21.95 \mathrm{ppm}$ $\left(\mathrm{N}\left(\mathrm{CH}_{2} \mathrm{CH}_{2} \mathrm{CH}_{3}\right)_{2}\right)$ and $\delta$ 54.53-54.76 ppm $\left(\mathrm{N}_{(}\left(\mathrm{CH}_{2} \mathrm{CH}_{2} \mathrm{CH}_{3}\right)_{2}\right)$. There is a slight difference for mono-alkylated compounds $\mathbf{2 a}, \mathbf{b}$, which showed the carbons of methyl groups at $\delta 11.52-11.59$ ppm), adjacent methylene groups at $\delta 23.53-23.55 \mathrm{ppm}$, and methylenes adjacent to the nitrogen at $\delta$ 46.16-46.49 ppm. Methylene carbons of the propylamino group at the 5-amino position appeared at $\delta$ 26.56-27.68 $\left(\mathrm{NHCH}_{2} \mathrm{CH}_{2} \mathrm{CH}_{2} \mathrm{NH}_{2} \cdot \mathrm{HBr}\right), \delta 42.63-42.97\left(\mathrm{NHCH}_{2} \mathrm{CH}_{2} \mathrm{CH}_{2} \mathrm{NH}_{2} \cdot \mathrm{HBr}\right)$ and $\delta 38.35-38.49$ ppm $\left(\mathrm{NHCH}_{2} \mathrm{CH}_{2} \mathrm{CH}_{2} \mathrm{NH}_{2} \cdot \mathrm{HBr}\right)$.<smiles></smiles>

$$
\begin{aligned}
& \text { 1a } \mathrm{R}=\left(\mathrm{CH}_{2}\right)_{2} \mathrm{CH}_{3}, \mathrm{R}_{1}=\left(\mathrm{CH}_{2}\right)_{3} \mathrm{NH}_{2} \cdot \mathrm{HBr} \\
& \text { 1b } \mathrm{R}=\left(\mathrm{CH}_{2}\right)_{2} \mathrm{CH}_{3}, \mathrm{R}_{1}=\mathrm{H} \\
& \text { 2a } \mathrm{R}=\mathrm{H}, \mathrm{R}_{1}=\left(\mathrm{CH}_{2}\right)_{3} \mathrm{NH}_{2} \cdot \mathrm{HBr} \\
& \text { 2b } \mathrm{R}=\mathrm{H}, \mathrm{R}_{1}=\mathrm{H}
\end{aligned}
$$

Figure 1. Structures of benzo[ $[a]$ phenoxazinium chlorides $\mathbf{1} \mathbf{a}, \mathbf{b}$ and $\mathbf{2} \mathbf{a}, \mathbf{b}$.

Photophysical properties of benzo[a]phenoxazinium chlorides $\mathbf{1} \mathbf{a}, \mathbf{b}$ and $\mathbf{2} \mathbf{a}, \mathbf{b}$ were evaluated through absorption and emission spectra of $10^{-6} \mathrm{M}$ solutions in ethanol acidified with TFA and aqueous solution at physiological $\mathrm{pH}$. The relative fluorescence quantum yields $\left(\Phi_{\mathrm{F}}\right)$ were determined using Oxazine 1 as a standard $\left(\Phi_{\mathrm{F}}=0.11\right.$ in ethanol $)$ at $590 \mathrm{~nm}$ excitation. Results are

\begin{tabular}{|c|c|c|c|c|}
\hline Compound & $1 \mathrm{1a}$ & $1 \mathrm{~b}$ & $2 a$ & $2 b$ \\
\hline \multicolumn{5}{|c|}{ Acidified ethanol } \\
\hline$\lambda_{\text {abs }}(\mathrm{nm})$ & 639 & 629 & 622 & 609 \\
\hline$\varepsilon\left(\mathrm{M}^{-1} \mathrm{~cm}^{-1}\right)$ & 39,920 & 67,500 & 32,301 & 65,800 \\
\hline$\lambda_{\text {emi }}(\mathrm{nm})$ & 669 & 662 & 655 & 646 \\
\hline$\Phi_{\mathrm{F}}$ & 0.18 & 0.20 & 0.35 & 0.47 \\
\hline$\Delta \lambda(\mathrm{nm})$ & 30 & 33 & 33 & 37 \\
\hline \multicolumn{5}{|l|}{$p H 7.4$} \\
\hline$\lambda_{\text {abs }}(\mathrm{nm})$ & 648 & 639 & 621 & 610 \\
\hline$\varepsilon\left(\mathrm{M}^{-1} \mathrm{~cm}^{-1}\right)$ & 33,622 & 62,425 & 17,250 & 35,093 \\
\hline$\lambda_{\mathrm{emi}}(\mathrm{nm})$ & 683 & 675 & 658 & 656 \\
\hline$\Phi_{\mathrm{F}}$ & 0.03 & 0.02 & 0.12 & 0.12 \\
\hline$\Delta \lambda(\mathrm{nm})$ & 35 & 36 & 37 & 46 \\
\hline
\end{tabular}
presented in Table 1.

Table 1. Photophysical data of compounds $\mathbf{1} \mathbf{a}, \mathbf{b}$ and $\mathbf{2} \mathbf{a}, \mathbf{b}$ in acidified ethanol and aqueous solution at pH $7.4\left(\lambda_{\text {exc }} 590 \mathrm{~nm}\right)$.

In acidic ethanol and pH 7.4 maximum absorption wavelengths ( $\left.\lambda_{\mathrm{abs}}\right)$ for all compounds lie in the range $609-648 \mathrm{~nm}$, with molar extinction coefficients $(\varepsilon)$ between 17,250 and $67,500 \mathrm{M}^{-1} \mathrm{~cm}^{-1}$. The maximum emission wavelengths $\left(\lambda_{\mathrm{emi}}\right)$ were found to be in the range of $646-683 \mathrm{~nm}$ at an excitation 
wavelength of $590 \mathrm{~nm}$, with moderate Stokes' shifts ( $\Delta \lambda, 30-46 \mathrm{~nm})$. In comparison, compounds $\mathbf{1 a}, \mathbf{b}$ displayed a bathochromic shift in both $\lambda_{\text {abs }}(17-29 \mathrm{~nm})$ and $\lambda_{\text {emi }}(14-25 \mathrm{~nm})$ in acidified ethanol and at physiological $\mathrm{pH}$. This is mainly due to the di-alkylation at the 9-amino position as previously observed [16]. Furthermore, compounds $1 \mathbf{a}$ and 2a, with an aminopropyl at the 5-amino position, show also a bathochromic shift comparing to compounds $\mathbf{1} \mathbf{b}$ and $\mathbf{2} \mathbf{b}$, which have a hydrogen atom at the same position. This indicates that the presence of an alkyl chain at the 5 -amino position of the benzophenoxazinium core increases the maximum absorption wavelength.

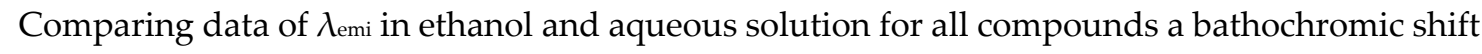
is observed at $\mathrm{pH} 7.4(3-14 \mathrm{~nm})$. Fluorescence quantum yields are higher for compounds $\mathbf{2 a , b}$ in both solvents, but decrease considerably at $\mathrm{pH} 7.4\left(\Phi_{\mathrm{F}} 0.12\right)$ comparing to ethanol $\left(\Phi_{\mathrm{F}} 0.35,2 \mathbf{2 a} ; 0.47, \mathbf{2 b}\right)$.

Figures 2 and 3 show normalized absorption and emission spectra of the four benzo[a]phenoxazinium chlorides in acidified ethanol and aqueous solution at physiological $\mathrm{pH}$, respectively.

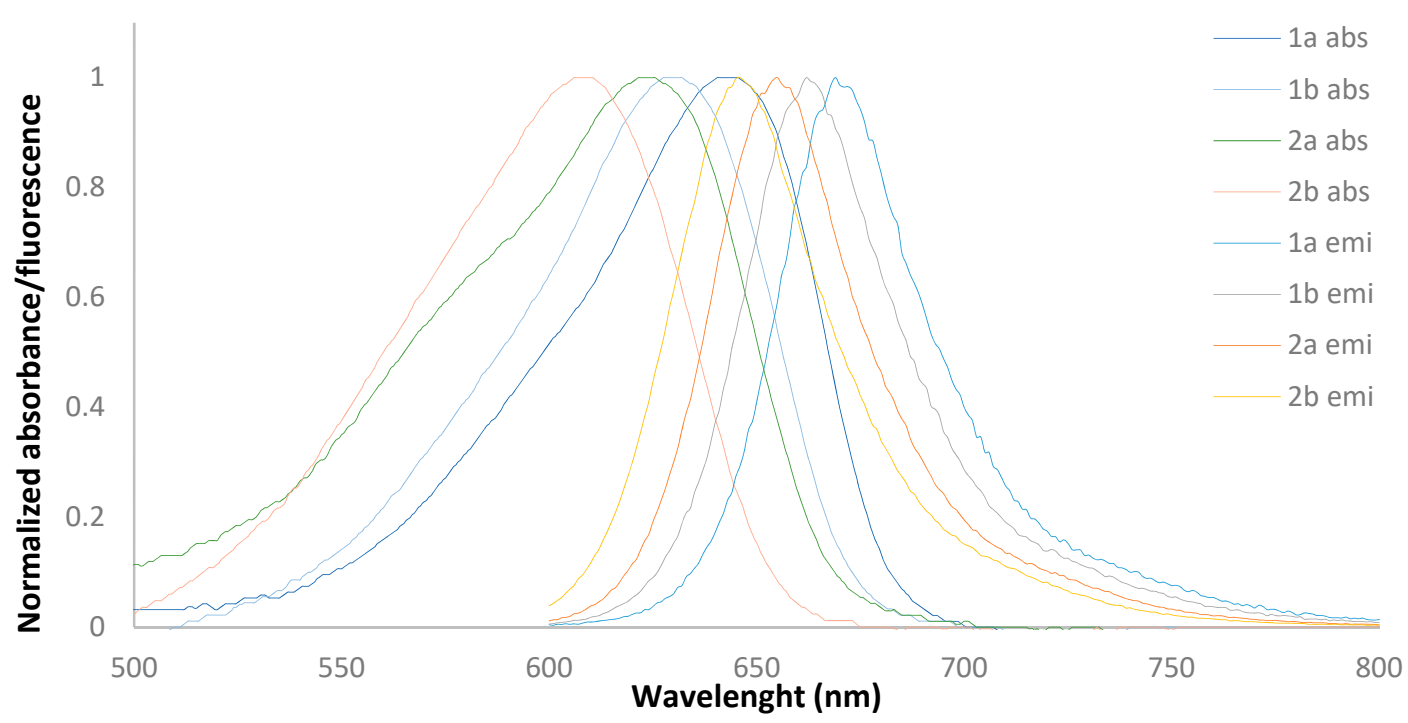

Figure 2. Normalized absorption and emission spectra of compounds $\mathbf{1} \mathbf{a}, \mathbf{b}$ and $\mathbf{2} \mathbf{a} \mathbf{a} \mathbf{b}$ in acidified ethanol.

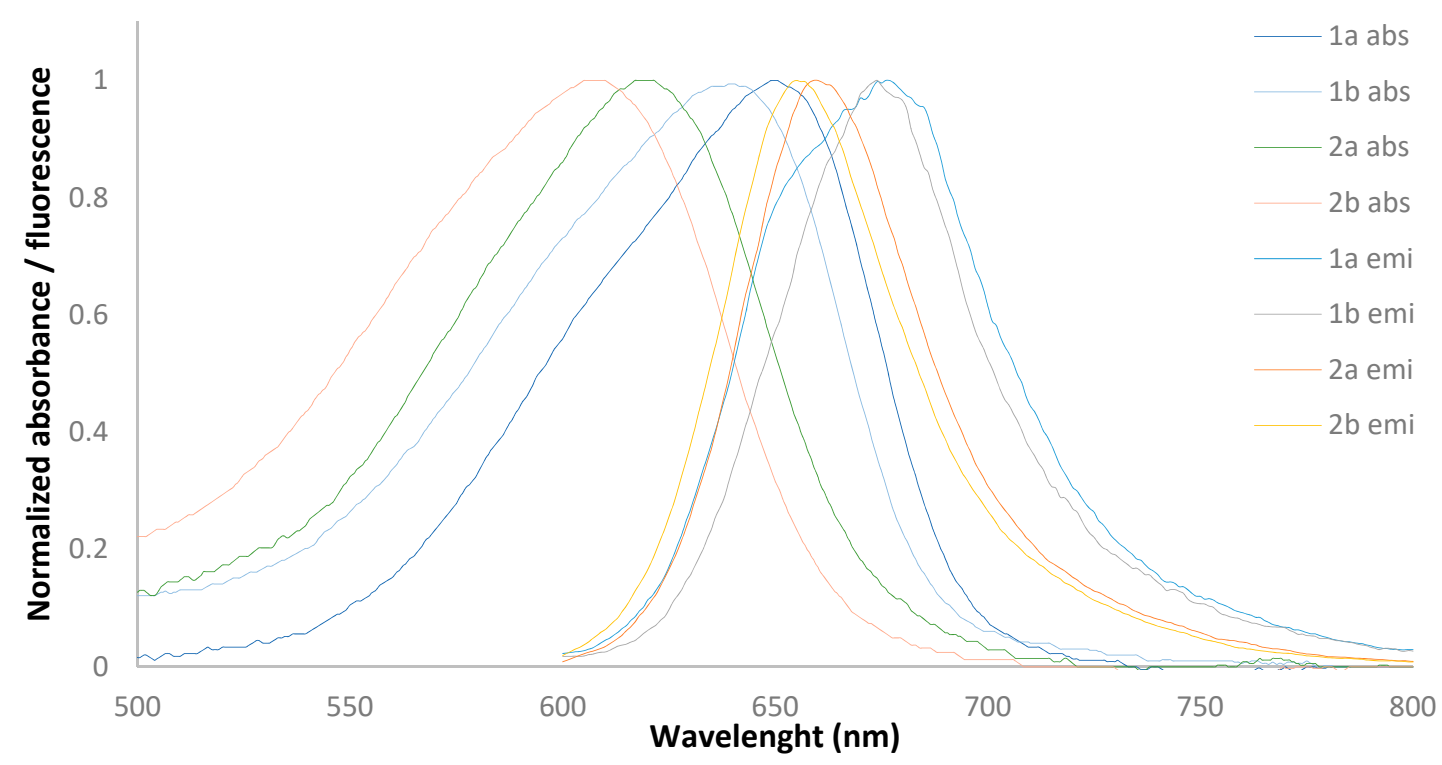

Figure 3. Normalized absorption and emission spectra of compounds $\mathbf{1} \mathbf{a}, \mathbf{b}$ and $\mathbf{2} \mathbf{a}, \mathbf{b}$ in aqueous solution at physiological $\mathrm{pH}$. 
Antifungal activity of benzo[a]phenoxazinium chlorides $\mathbf{1} \mathbf{a}, \mathbf{b}$ and $\mathbf{2} \mathbf{a}, \mathbf{b}$ was measured against Saccharomyces cerevisiae PYCC 4072. Minimum Inhibitory Concentration (MIC) values indicate the minimum concentration of each compound in which the yeast growth is inhibited by $\geq 80 \%$. Log $P$ is an estimated measure of the compounds' hydrophobicity by calculating the partition between membranes and aqueous media (Table 2).

Table 2. MIC values of compounds $\mathbf{1} \mathbf{a}, \mathbf{b}$ and $\mathbf{2} \mathbf{a}, \mathbf{b}$ against Saccharomyces cerevisiae PYCC 4072.

\begin{tabular}{ccc}
\hline Compound & MIC $(\boldsymbol{\mu M})$ & $\log \boldsymbol{P}$ \\
\hline $\mathbf{1 a}$ & 25 & 1.15 \\
$\mathbf{1 b}$ & 25 & 1.70 \\
$\mathbf{2 a}$ & 25 & 1.09 \\
$\mathbf{2 b}$ & 6.25 & 1.64 \\
\hline
\end{tabular}

Compound $2 \mathrm{~b}$ have a MIC value of $6.25 \mu \mathrm{M}$, while the other three compounds have $25 \mu \mathrm{M}$. Previous work appeared to show di-alkylation at the 9-amino position improved antifungal activity comparing to mono-alkylation [14]. However, this work showed compound $\mathbf{2} \mathbf{b}$ (only one alkyl chain at 9-position) has a lower MIC value than analogues, indicating that biological activity may relate to the combination of all substituents and no correlation between MIC value and the number of alkylic chains at the 9-amino position can be established. No correlation between MIC values and Log $P$ values is established either.

\section{Experimental}

Typical procedure for the preparation of compounds $\mathbf{1} \boldsymbol{a}, \boldsymbol{b}$ and $\mathbf{2} \boldsymbol{a}, \boldsymbol{b}$ (illustrated for $\mathbf{2} \boldsymbol{b}$ )

To a solution of 5-(propylamino)-2-nitrosophenol hydrochloride (0.408 g, $1.88 \times 10^{-3} \mathrm{~mol}, 2 \mathrm{eq}$.) in methanol $(3 \mathrm{~mL})$, concentrated hydrochloric acid $(0.724 \mathrm{~mL})$ was added followed by naphthalen-1-amine $\left(0.135 \mathrm{~g}, 9.4 \times 10^{-4} \mathrm{~mol}, 1 \mathrm{eq}.\right)$, and the resulting solution was refluxed for $24 \mathrm{~h}$. The progress of the reaction was monitored by TLC (dichloromethane/methanol 9:1). After evaporation of the solvent and column chromatography purification on silica gel (mixtures of increasing polarity of dichloromethane/methanol as the eluent), $\mathrm{N}$-(5-amine-9H-benzo[ $a$ ] phenoxazin-9ilidene)propane-1-aminium chloride was obtained as a blue solid $(0.157 \mathrm{~g}, 49 \%)$. $\delta_{\mathrm{H}}\left(\mathrm{CD}_{3} \mathrm{OD}, 400\right.$ $\mathrm{MHz}) 1.07\left(\mathrm{t}, J=7.2 \mathrm{~Hz}, 3 \mathrm{H}, \mathrm{NHCH}_{2} \mathrm{CH}_{2} \mathrm{CH}_{3}\right), 1.78$ (sext, $\left.J=7.2 \mathrm{~Hz}, 2 \mathrm{H}, \mathrm{NHCH}_{2} \mathrm{CH}_{2} \mathrm{CH}_{3}\right), 3.51(\mathrm{t}, J=$ $\left.7.6 \mathrm{~Hz}, 2 \mathrm{H}, \mathrm{NHCH}_{2} \mathrm{CH}_{2} \mathrm{CH}_{3}\right), 6.98$ (s, $2 \mathrm{H}, \mathrm{H}-6$ and H-8), 7.26 (d, J = 9.4 Hz, 1H, H-10), 7.88-7.95 (m, 2H, H-3 and H-11), $8.02(\mathrm{dt}, J=8.0$ and $0.8 \mathrm{~Hz}, 1 \mathrm{H}, \mathrm{H}-2), 8.39(\mathrm{~d}, J=8.0 \mathrm{~Hz}, 1 \mathrm{H}, \mathrm{H}-4), 8.96(\mathrm{dd}, J=8.0$ and $0.8 \mathrm{~Hz}, 1 \mathrm{H}, \mathrm{H}-1)$ ppm. $\delta \mathrm{c}\left(\mathrm{CD}_{3} \mathrm{OD}, 100.6 \mathrm{MHz}\right) 11.52\left(\mathrm{NHCH}_{2} \mathrm{CH}_{2} \mathrm{CH}_{3}\right), 23.53\left(\mathrm{NHCH}_{2} \mathrm{CH}_{2} \mathrm{CH}_{3}\right)$, $46.16\left(\mathrm{NHCH}_{2} \mathrm{CH}_{2} \mathrm{CH}_{3}\right), 98.29$ (C-8), 98.86 (C-6), 113.04 (C-10), 124.75 (Ar-C), 125.08 (C-4), 126.09 (C-1), 130.43 (Ar-C), 131.60 (C-3), 132.68 (C-11), 133.29 (Ar-C), 134.21 (C-2), 144.49 (Ar-C), 152.40 (2 × Ar-C), 153.01 (C-9), 164.62 (C-5) ppm.

Procedure for antifungal activity tests

Minimum inhibitory concentration of growth for the different compounds was determined using a broth microdilution method for the antifungal susceptibility testing of yeasts (M27-A3, CLSI-Clinical and Laboratory Standards Institute). Cells were incubated at $30{ }^{\circ} \mathrm{C}$ in RPMI 1640 medium, buffered to $\mathrm{pH} 7.0$ with $0.165 \mathrm{M}$ morpholenepropanesulfonic acid (MOPS) buffer. Initial cell concentration was $2.25 \times 10^{3}$ cells $/ \mathrm{mL}$. Stock solutions of the compounds were prepared in DMSO and a final dilution was carried out in an RPMI 1640 medium (DMSO concentrations of 0.5\% per well). MIC values were determined using a microplate photometer, after $48 \mathrm{~h}$ of incubation, as the lowest concentration of drug that resulted in a growth inhibition over $80 \%$, as compared to the growth observed in the control wells containing 0.5\% DMSO. Each drug concentration was tested in triplicate and in two independent experiments. 


\section{Conclusions}

Four new benzo $[a]$ phenoxazinium chlorides were successfully synthesized. Photophysical studies in acidic ethanol and aqueous solution at physiological $\mathrm{pH}$ showed that compounds display fluorescence with $\lambda_{\text {emi }}$ between 646 and $683 \mathrm{~nm}$, and fluorescent quantum yields up to 0.47 , being the highest values related to compound with propyl and aminopropyl groups at 9- and 5-positions, respectively. All compounds revealed good antifungal activity, with benzo[ $a]$ phenoxazinium with the later combination of substituents presenting the best result, a MIC value of $6.25 \mu \mathrm{M}$.

Acknowledgments: Thanks are due to Fundação para a Ciência e Tecnologia (FCT) and FEDER (European Fund for Regional Development)-COMPETE-QRENEU for financial support through the Chemistry Research Centre of the University of Minho (Ref. UID/QUI/00686/2013 and UID/QUI/0686/2016), CBMA (PEst-OE/BIA/UI4050/2014) and a PhD grant to J.C.F. (SFRH/BD/133207/2017). The NMR spectrometer Bruker Avance III 400 is part of the National NMR Network (PTNMR) and are partially supported by Infrastructure Project No 022161 (co-financed by FEDER through COMPETE 2020, POCI and PORL and FCT through PIDDAC).

Conflicts of Interest: The authors declare no conflict of interest.

\section{References}

1. Gonçalves, M.S.T. Fluorescent Labeling of Biomolecules with Organic Probes. Chem. Rev. 2009, 109, 190212, doi:10.1021/cr0783840.

2. Zhou, K.; Li, Y.; Peng, Y.; Cui, X.; Dai, J.; Cui, M. Structure-Property Relationships of Polyethylene Glycol Modified Fluorophore as Near-Infrared A $\beta$ Imaging Probes. Anal. Chem. 2018, 90, 8576-8582, doi:10.1021/acs.analchem.8b01712.

3. Wang, J.; Xia, S.; Bi, J.; Fang, M.; Mazi, W.; Zhang, Y.; Conner, N.; Luo, F.T.; Lu, H.P.; Liu, H. Ratiometric Near-Infrared Fluorescent Probes Based on Through-Bond Energy Transfer and $\pi$-Conjugation Modulation between Tetraphenylethene and Hemicyanine Moieties for Sensitive Detection of $\mathrm{pH}$ Changes in Live Cells. Bioconjugate Chem. 2018, 29, 1406-1418, doi:10.1021/acs.bioconjchem.8b00111.

4. Yeo, D.; Wiraja, C.; Miao, Q.; Ning, X.; Pu, K.; Xu, C. Anti-scarring Drug Screening with Near-Infrared Molecular Probes Targeting Fibroblast Activation Protein- $\alpha$. ACS Appl. Bio Mater. 2018, 1, 2054-2061.

5. Martinez, V.; Henary, M. Nile Red and Nile Blue: Applications and Synthesis of Structural Analogues. Chem. Eur. J. 2016, 22, 13764-13782, doi:10.1002/chem.201601570.

6. Frade, V.; Barros, S.A.; Moura, J.C.; Coutinho, P.J.; Gonçalves, M.S.T. Synthesis of Short and Long-Wavelength Functionalised Probes: Amino Acids Labelling and Photophysical Studies. Tetrahedron 2007, 63, 12405-12418, doi:10.1002/anie.201600521.

7. Alves, C.M.A.; Naik, S.; Coutinho, P.J.G.; Gonçalves, M.S.T. Novel Long Alkyl Side-chain Benzo[a]phenoxazinium Chlorides: Synthesis, Photophysical Behaviour and DNA Interaction. Tetrahedron 2009, 65, 10441-10452, doi:10.1016/j.tet.2009.10.017.

8. Raju, B.R.; Naik, S.; Coutinho, P.J.G.; Gonçalves, M.S.T. Novel Nile Blue Derivatives as Fluorescent Probes for DNA. Dyes Pigment. 2013, 99, 220-227, doi:10.1016/j.dyepig.2013.05.007.

9. Raju, B.R.; Gonçalves, M.S.T.; Coutinho, P.J.G. Fluorescent Probes Based on Side-chain Chlorinated Benzo[a]phenoxazinium Chlorides: Studies of Interaction with DNA. Spectrochim. Acta 2017, 171, 1-9, doi:10.1016/j.saa.2016.07.030.

10. Naik, S.; Alves, C.M.A.; Coutinho, P.J.G.; Gonçalves, M.S.T. N-(Di)Icosyl-Substituted Benzo[a]phenoxazinium Chlorides: Synthesis and Evaluation as Near-Infrared Membrane Probes. Eur. J. Org. Chem. 2011, 2011, 2491-2497, doi:10.1002/ejoc.201001579.

11. Hu, M.; Yin, J.; Li, Y.; Zhao, X. Development of a Nile-Blue Based Chemodosimeter for $\mathrm{Hg}^{2+}$ in Aqueous Solution and Its Application in Biological Imaging. J. Fluoresc. 2015, 25, 403-408, doi:10.1007/s10895-015-1527-z.

12. Lopes, M.; Alves, C.T.; Raju, B.R.; Gonçalves, M.S.T.; Coutinho, P.J.; Henriques, M.; Belo, I. Application of Benzo[a]phenoxazinium Chlorides in Antimicrobial Photodynamic Therapy of Candida albicans Biofilms. J. Photochem. Photobiol. B 2014, 141, 93-99, doi:10.1016/j.jphotobiol.2014.09.006.

13. Frade, V.H.J.; Sousa, M.J.; Moura, J.C.V.P.; Gonçalves, M.S.T. Synthesis of Naphtho[2,3-a]phenoxazinium Chlorides. Structure-Activity Relationships of These Heterocycles and Benzo[a]phenoxazinium Chlorides as New Antimicrobials. Bioorg. Med. Chem. 2008, 16, 3274-3282, doi:10.1016/j.bmc.2007.12.013. 
14. Leitão, M.I.; Raju, B.R.; Naik, S.; Coutinho, P.J.; Sousa, M.J.; Gonçalves, M.S.T. Synthesis and Photophysical Studies of New Benzo[a]phenoxazinium Chlorides as Potential Antifungal Agent. Tetrahedron Lett. 2016, 57, 3936-3941, doi:10.1016/j.tetlet.2016.07.065.

15. Mizukawa, Y.; Ge, J.F.; Md, A.B.; Itoh, I.; Scheurer, C.; Wittlin, S.; Brun, R.; Matsuoka, H.; Ihara, M. Novel Synthetic Route for Antimalarial Benzo[a]phenoxazine Derivative SSJ-183 and Two Active Metabolites. Bioorg. Med. Chem. 2014, 14, 3749-3752, doi:10.1016/j.bmc.2014.04.066.

16. Frade, V.H.J.; Gonçalves, M.S.T.; Coutinho, P.J.G.; Moura, J.C.V.P. Synthesis and Spectral Properties of Long-Wavelength Fluorescent Dye. J. Photochem. Photobiol. 2007, 185, 220-230, doi:10.1016/j.jphotochem.2006.06.013.

(C) 2019 by the authors. Licensee MDPI, Basel, Switzerland. This article is an open access article distributed under the terms and conditions of the Creative Commons Attribution (CC BY) license (http://creativecommons.org/licenses/by/4.0/). 